\title{
Brain Drain Techniques in Revolution 2020
}

\section{M.Mareeswari}

\begin{abstract}
Chetan Bhagat, being a prominent contemporary Indian novelist, explores the various facts related to youth power in India. Bhagat writes about every aspect of society in his novels. His novels are not merely a photographic picture of society, but a reflection of a particular moment. In this novel Revolution 2020, Bhagat effort has been taken to expose the faulty educational system. It is one of the dominent themes in his novel. With the help of this theme Bhagat tried to show that, students are not in a position to cope with the syllabus. Students are treated as machines. With the help of this novel Bhagat shows students are not rated on the basis of their innovative ideas. They don't like the teaching method. The students are rated on the basis of how much they perform in their exams. The education system of IIT, Delhi depicted in this novel is criticised. Bhagat finds that IIT education is not sufficient for the overall development of personality. It adheres to the same patriarchal norms and codes of education where students are so much overloaded with assignments, class tests and major exams. In this situation, they forget the real meaning of life. The education is for life and not only for securing a job. Every student tries to learn their subjects by heart but the system is not working very well. The students have to mug up their subject. Today's new generation always comments regarding their study and they always blame the educational system.
\end{abstract}

Keywords : innovative, generation, personality, reflection, Revolution

\section{INTRODUCTION}

The novelist, Bhagat touches upon the sensitive issues of Faulty Education System. He presents today's corrupt practices involved in Educational System. He has expressed the view of education in Revolution 2020 in a broad way.

Bhagat believes that educational should provide profit to the industry players. The mindset that education should be non- profitable is to be changed. The government should clear the policy that the private institutes should be run by non-profit trusts. The government believes that you should not make money from education. They take out the money illegally in cash and on paper maintain the non-profit status.

\section{METHODOLOGY}

Bhagat tries to show that the good quality leaders to take interest in the field of education for value education. In this novel, Bhagat criticises Faulty Education System through the protagonist's failure to seek admission in a reputed college and the same fellow become successful to open an engineering college with support of a politician. But also the crisis of the system that is a failure to ensure stable future both for the individuals and to the nation. The world needs good people. He has a realisation of the fact that education would be a failure without providing opportunities for all-round development of human personalities.

Revised Manuscript Received on December 20, 2019.

M.Mareeswari*, Department of English, Kalasalingam Academy of Research and Education, Krishnankovil, Virudunagar, Tamilnadu, India.
The technical education that promotes technical skills and rational attitude cannot ensure security and happiness to the youths. He classifies the intellectual into two categories lerds and nerds (combination and socially embarassing). He defines nerds as people slavishly devoted to academic pursuits. Some people are supposed to be intelligent but socially awkward. They remain disconnected from the real world. Not every person with a technical background is socially efficient. Such intellectual giants can grab the theoretical reality of the things but can't articulate their voice in context of the real life conditions. They can express themselves on the variety of topics like environment, corruption, poverty eradication, health care, infrastructure, etc.

According to Bhagat, reorientation of the society is possible through the application of new educational strategies in humanities as well. The dry knowledge leads to stagnation. He teaching materials and methods in humanities is outdated. Many postgraduates have excellent knowledge in their subject but they can't apply it in their day today life

Bhagat warns us that we are destroying an entire generation by not giving it access to the world- class education which it deserves. He admits education must be free from the shadows of commercialisation. The entire speculation on this aspect of education has become the central theme of this topic. He accepts that the national policy of education can no longer correspond with needs and cries of the nation. The conventional Indian education is not sufficient to meet the higher needs of life.

Sufficient economic sources are required to meet the demands of society. Reflecting on the miserable Indian education system, Bhagat states that advanced concepts in education to satisfy curiosity or learning for sake does not apply to people with no money. He highlights a hungry person does not watch a discovery channel.

Bhagat also been criticised the existing colonial practices in educational system. Children are not permitted to develop their own points of view. The originality of thinking and innovative spirit is missing. Bhagat mentions at school, our education system hammers out our individual voices and kills our natural creativity, turning us into service course material scar. Indian kids can't their voice in their class especially when they are against the opinion of their teachers. According to Bhagat no subject teaches us own imagination, own creativity or own innovation. Course materials are designed for non-debate kind of teaching. He also raises the question of accountability of education. The structure of education is not organised to acknowledge the accountability of hidden potential.

Bhagat rightly remarks in The Times of India article entitled "where is my nobel prize". In this article he opines: the talent isn't being put on the highest platform in India. The actual talent seems to have the least preference. Even in IIT, a truly exceptional young faulty cannot jump ranks and scales set up by the ineffective system. Such a broad vision about the 
present education system furnished Bhagat with new narrative mirror to pick up his themes and locals from the top educational institutes of India. Educational and its associate practices emerge as the central motif in his novels. The business of education has become a safer cover to complete all black designs. In the prologue of the novel, he makes a declaration of his vision and mission of life.

Bhagat avoids writing columns on the Indian education system as it is not good for his health. He feels insomnia and feel like hurting someone real bad. The Indian education system is problematic. It affects youth future. This obsession for the admission in NITs has become the focal point of the novel. For Gopal's father, the only dream was to look to the success of Gopal in NIT. Aarti is only exception who dreams of being an air hostess without any intention of admission in AIEEE. It is becoming a cause of stress mind and depression in the life of youths. Bhagat accepts futility of education system..

Bhagat in the depression of Gopal captures the psyche of the failure governing the life of those who aim at being the top rankers among the taste takers of AIEEE. Gopal out of embarrassment and disappointment fails to compromise with his real position. He tries to make Baba realise the reality nine lakh fifty thousand of them didn't.

In the present scenerio, Kota is another sort of illusion gathers the young technical aspirants from all the corners of the world. These coaching institutes are only mode of business mind like us the opportunities of self- employment to the academicians, organisers and financers. Kota is presented in Revolution 2020 as a gateway of success and opportunities, the gateway to IIT, "An IIT rank is a huge event-akin to climbing the Mount Everest or being on a space mission" (page 39). Gopal realises to Baba has realisation of Gopal wants to education is not easily for limited amount of money. Baba says, "And how will you do a repent attempt without better coaching?". Gopal's father advised him to go to kota to crack the exams of AIEEE or JEE. His Baba said; "Look-at Raghav, yes, the new medicine being shoved down every Varanasi kid's throat right now". (page41).

Bhagat has presented the inspiring picture of Kota. But Gopal become nervous when he reached at Kota. Because of the workers are laughed at him especially the auto-driver, he realised the illusions and temptations for students and are all collectively presented to expose the creeping illusions ruining the life and sensibility of young technocrats.

Bhagat clearly exposes that the Gopal's life and real struggle is not to seek rank in AIEEE but to clear the entrance tests of these institutions. Gopal has the satisfaction of being "Short listed for five coaching institutes like us Bansal, Career path, Resonance and Two new, Cheaper one called aim IIT and career ignite" (page 57). Bhagat makes use of striking images. Gopal appreciates the magnificent buildings of tuition centres but ridicules the mechanical interaction between students and teachers. He acknowledges, "Students and teachers strode about in a purposeful manner, as if they were going to launch statellites in space" (page 59).

Gobal ultimately fails to quality AIEEE and the only possible option with Gobal remains, is to knock the door of any private college like Riddhi Siddhi Technical College.
Through the inner consciousness of Gopal, Bhagat moves to expose the horrible conditions of private colleges. They ensure the collapse of the youth of India. In these private colleges, students are pushed in such a mud from where no escape route is possible for them.

However, the only option for Gopal after Baba's death was to seek admission in Sri Ganesh Vinayaka College. These colleges are not the centres of learning but they are the centres of minding money. Every day is being counted only in terms of making more and more profit..

Irony is constant in the hidden agenda of this 'Give and Take' process. Students are expected to invest more than their capacity to secure better job. Further, like a business deal, students are counting in terms of investments and discounts. "Tell me your budget. I will give you a ten percent discount if you sign up right now" (page 114). When Gopal unable to complete his education he decided to sold his father's disputed land. Shukla suggests Gopal to open a new college on the disputed land.

Chetan Bhagat comes across how the private institutes earn a lot of money. At the same time, he throws lights how one can easily get the university connecting. They can't provide value education to the future generation. It has clearly portrayed the administrative polices of getting the university connecting by recite Mr. Bedi's speech which guides Gopal as:

No, any government work, especially in education our country envelope would do the trick (page 138).

Bhagat's vision was stimulated by the various proportions of the education patterns gripping the social constructs. The students are obessed with the passion for seeking admission in the most prestigious institution of India. The anxiety of admission is creating confusion in the life of the youth. There is an improper strength of students in our universities and colleges. Universities are being preferred to the college. Pathetically lakhs of the seats are vacant in the thousands of colleges.

The theme of faulty education system shows that it is very difficult for the honest person. They cannot open a new college without giving to much bribery (corruption). The educational field is also not an exception from this bitter truth. Bhagat in his novel The Times of India's article entitled "The Business of Teaching" rightly remarks that corruption in the field of education should be taken very seriously. According to Bhagat; educational system in India has been badly shaken with illegal means. The adultery practices have affected the entire system. Indian government is responsible for destroying an entire generation by not giving it access to the world- class education it deserves.

It reflects corruption that and wrong policies have prevailed even in the pious field of education. Bhagat also expresses education has become the domain of those people who have nothing to do with education. Any liquor baron, can open the college and we are handover our generations future in their hands. People should strive to form a society in which neither the students nor the teachers are being exploited. The scenerio in the education field is very depressing where the teacher has to work for the salary, how can he keep himself away from the worldly cards? When most of the government teachers 
enjoy the benefits of sixth pay commission, it is a big question mark how many private colleges even offer the fifth pay commission to their employees? Still there is always a ray of hope, as Bhagat shows the solution of this burning issue in his The Times of India's article entitled "The Business of Teaching" he rightly remarks: Our educational system can be accurate internally with the help of various outside sources. It can complete with the best global systems if collective efforts are being taken.

\section{CONCLUSION}

The higher education becomes business for many and ironically business of none. They thought that ' $E$ ' is not for education it is only for earning. No education in a college. Instead of offering rosy dreams to the students, government should take some action for purifying this pious field. The faith of the students will turn into a tsunami.

\section{REFERENCES}

1. Bhagat Chetan, Revolution 2020. Rupa publication India Pvt. Ltd. New Delhi: 2011.

2. Bhagat, Chetan. What Youn India Wants. First. New Delhi: Rupa Publication Pvt. Limited, 2012.Print.

3. Banerjee, Prasun. The Choreoghraphed Narrative:Recontextulising the Narrative Strategies in Chetan Bhagat's Fiction.The Creiterion: An Intrnational Journal in English (2012) Print.

4. Kumar, sanjay. Social Conceptualization in the novels of Anita Nair, Chetan Bhagat and Arvind Adiga.(n.d.).Print.

5. Rodrigues, Dr. Joseph. A Critial Review In 'Revolution 2020'-an Amalgam of Socio-Political Commercialization Wolrd Combined with Love Triangle.Global Journal Reserch For Analysis (2014) Print.

6. Somwanshi, A. P. Social Realism in R. K. Narayan and Chetan Bhagat' Novels : A comparion. Vishwabharati (2012) Print.

7. Sreelatha, M. Chetan Bhagat and Aravind Adiga as Social Critics: Comparing Revolution 2020 and The White Tiger. Dhavan, Tapan K Ghosh \& R. K. Chetan Bhagat: The Icon of the Popular Fiction. New Delhi: Prestige Book International, 2014. Print.

\section{AUTHORS PROFILE}

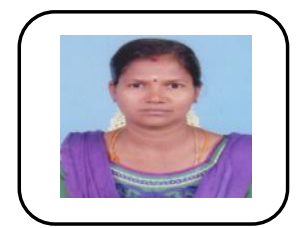

M. Mareeswari, A ssistant Professor, Department of English, Kalasalingam Academy of Research and Education, Virudhunagar, Tamil Nadu- India 